\title{
Ecocide and Genocide in Iraq: International Law, the Marsh Arabs, and Environmental Damage in Non-International Conflicts
}

Aaron Schwabach

University of Arkansas at Litle Rock William H. Bowen School of Law, aschwabach@ualr.edu

Follow this and additional works at: https://lawrepository.ualr.edu/faculty_scholarship

Part of the Environmental Law Commons, International Humanitarian Law Commons, and the International Law Commons

\section{Recommended Citation}

Aaron Schwabach, Ecocide and Genocide in Iraq: International Law, the Marsh Arabs, and Environmental Damage in Non-International Conflicts, 15 Colo. J. Int'l Envtl. L. \& Pol'y 1 (2004).

This Article is brought to you for free and open access by Bowen Law Repository: Scholarship \& Archives. It has been accepted for inclusion in Faculty Scholarship by an authorized administrator of Bowen Law Repository: Scholarship \& Archives. For more information, please contact mmserfass@ualr.edu. 


\title{
Articles
}

\section{Ecocide and Genocide in Iraq: International Law, the Marsh Arabs, and Environmental Damage in Non-International Conflicts}

\author{
Aaron Schwabach ${ }^{*}$
}

\section{INTRODUCTION}

Modern warfare has the potential to inflict enormous damage upon the natural environment. In the post-Cold War world, few areas have suffered greater environmental harm from wartime military activities than the area in and around Iraq. Three of the most extreme instances were inflicted by the former Iraqi government. In the first Gulf War, Iraqi forces set fire to 600 of Kuwait's oil wells and uncapped or damaged 175 more.' During the same conflict at least six million barrels of oil were deliberately discharged into the Persian Gulf, ${ }^{2}$ adding to the already considerable damage wrought by routine oil industry operations and the hundreds of attacks on tankers and oil facilities during the Iran-Iraq war. ${ }^{3}$ And following the unsuccessful

- Aaron Schwabach received a J.D. from the University of California at Berkeley, Boalt Hall, in 1989. He is currently a Professor of Law at Thomas Jefferson School of Law.

1. The Spoils of War: What Can the Past Tell About the Effect of Military Conflict on the Environment?, ECONOMIST, Mar. 27, 2003 [hereinafter "Spoils of War"].

2. Id.

3. See Michael N. Schmitt, Green War: An Assessment of the Environmental Law of International Armed Conflict, 22 YALE J. INT'L L. 1, 14 (1997). 
Shiite rebellion of 1991, Saddam Hussein's government drained the marshlands of Southern Iraq in a successful effort to destroy the lifestyle and culture of the Shiite Ma'Dan, or Marsh Arabs. ${ }^{4}$

The illegality of the Iraqi actions against the environment during the Gulf War, which resulted in an unprecedented imposition of damages for environmental harm, ${ }^{5}$ has been fully discussed elsewhere. ${ }^{6}$ The plight of the Marsh Arabs has received less attention from legal scholars than perhaps it should, possibly owing to a lack of information about the region or to the obscurity of international law concerning domestic environmental damage. ${ }^{7}$ This article addresses the legality of the actions against the Marsh

4. The Marsh Arabs of Iraq: Do They Want to Go Back in Time?, ECONOMIST, June 5, 2002, at http://www.economist.com/PrinterFriendly.cfm?Story_ID=1827561 (last visited November 22, 2003) [hereinafter Marsh Arabs].

5. See S.C. Res. 687, U.N. SCOR, 46th Sess., 2981st mtg., U.N. Doc. S/RES/687 (1991); see also S.C. Res. 674, U.N. SCOR, 45th Sess., 2951st mtg., U.N. Doc. S/RES/674 (1990); see also S.C. Res. 686, U.N. SCOR, 46th Sess., 2978th mtg., U.N. Doc. S/RES/686 (1991).

6. On the damage to Kuwait and the Persian Gulf, see, for example, Margaret $\mathrm{T}$. Okorodudu-Fubara, Oil in the Persian Gulf: Legal Appraisal of an Environmental Warfare, 23 ST. MARY's L.J. 123 (1991); Betsy Baker, Legal Protections for the Environment in Times of Armed Conflict, 33 VA. J. INT'L L. 351 (1993) (see esp. n.5, listing academic conferences on this topic); Luan Low \& David Hodgkinson, Compensation for Wartime Environmental Damage: Challenges to International Law After the Gulf War, 35 VA. J. INT'L L. 405 (1995); Major Walter G. Sharp, Sr., The Effective Deterrence of Environmental Damage During Armed Conflict: A Case Analysis of the Persian Gulf War, 137 MIL. L. REV. 1 (1992); Florentino P. Feliciano, Marine Pollution and Spoliation of Natural Resources as War Measures: A Note on Some International Law Problems in the Gulf War, 14 Hous. J. INT'L L. 483 (1992); Philippe Sands, Moderator, The Gulf War: Environment As a Weapon, 85 AM. SoC'Y INT'L L. PROC. 214 (1991); Marc A. Ross, Comment, Environmental Warfare and the Persian Gulf War: Possible Remedies to Combat Intentional Destruction of the Environment, 10 DICK. J. INT'L L. 515 (1992); Suzanne M. Bernard, Comment, Environmental Warfare: Iraq's Use of Oil Weapons During the Gulf Conflict, 6 N.Y. INT'L L. REV. 106 (1993); Shilpi Gupta, Note, Iraq's Environmental Warfare in the Persian Gulf, 6 GEO. INT'L ENVTL. L. REV. 251 (1993); Mark J. T. Caggiano, Comment, The Legitimacy of Environmental Destruction in Modern Warfare: Customary Substance over Conventional Form, 20 B.C. ENVTL. AFF. L. REV. 479 (1993); Laura Edgerton, Note, Eco-Terrorist Acts During the Persian Gulf War: Is International Law Sufficient to Hold Iraq Liable? 22 GA. J. INT'L \& COMP. L. 151 (1992); Stephanie N. Simonds, Note, Conventional Warfare and Environmental Protection: $A$ Proposal for International Legal Reform, 29 STAN. J. INT'L L. 165 (1992); Jesica E. Seacor, Note and Comment, Environmental Terrorism: Lessons from the Oil Fires of Kuwait, 10 AM. U.J. INT'L L. \& POL'Y 481 (1994).

7. However, several articles discuss or mention the plight of the Marsh Arabs. See, e.g., Michael Posner \& Fiona McKay, The Iraqi Justice System: Challenges in Responding to Iraq's Past Abuses of Human Rights, 42 JUDGES J. 14, 15 (2003); Suzette Brooks Masters, Environmentally Induced Migration: Beyond a Culture of Reaction, 14 GEO. IMMIGR. L. J. 855, 867-68 (2000); Joseph W. Dellapenna, The Two Rivers and the Lands Between: Mesopotamia and the International Law of Transboundary Waters, 10 
Arabs and the wetlands in which they lived.

\section{THE MARSH ARABS}

r

Before the first Gulf War, Southern Mesopotamia held southwestern Asia's most extensive wetlands, at the confluence of the Tigris and the Euphrates. $^{8}$ For thousands of years these wetlands, spreading out on all sides of the Tigris, the Euphrates, and the Shatt al-Arab, had been occupied by the ancestors of the people known today as the Marsh Arabs, whose culture was uniquely adapted to the marsh environment. ${ }^{9}$ The culture of the Marsh Arabs, existing in harmony with the marsh environment, was completely dependent on marsh resources: the plants, animals and water of the marshes. The duration of the culture testifies to the sustainability of its uses of those resources. The reeds that grew in the marshes were the primary building material for houses and boats; the fish and waterfowl of the marshes were a primary source of food. ${ }^{10}$ The marshes themselves were known to outsiders for their spectacular displays of spring wildflowers. ${ }^{11}$

In recent times, the Marsh Arabs, like a majority of Iraqis, have been Shi'a Muslims. In 1991, after the first Gulf War, the Marsh Arabs and other Shiites in southern Iraq rose up in an unsuccessful attempt to overthrow or at least throw off the control of the Hussein government. ${ }^{12}$ The government responded with a nationwide propaganda campaign labeling the Marsh Arabs as "monkey-faced" outsiders, ${ }^{13}$ followed by an attack on the environment that sustained Marsh Arab society. Over the next few years, the government built a system of dams, dikes and canals to drain the wetlands, so that today only seven percent of the original area remains. ${ }^{14}$ Today the Mesopotamian wetlands are parched earth crusted with salt; the

B.Y.U. J. PUB. L. 213, 219-20, 224 (1996).

8. See, e.g., Colin Freeman, Marsh Arabs Reclaim Paradise, IRAQ OCCUPATION WATCH, August 16, 2003, at http://www.occupationwatch.org/article.php?id=493 (last visited 10/17/2003). The frequent references to "Eden" and "Paradise" in discussions of the Marsh Arabs reflect the belief that the Garden of Eden was located in the region.

9. See id.; see also Spoils of War, supra note 1; Marsh Arabs, supra note 4.

10. See Wilfred Thesiger, Marsh Dwellers of Southern Iraq: Primitive Ma'dan, Building Cathedral-like Houses of Reeds, Share a Watery Domain with Buffaloes and Wild Boars, 108 NAT'L GEOGRAPHIC 205 (1958).

11. Id. at 205, 232.

12. See, e.g., Marsh Arabs, supra note 4.

13. JOHN FAWCETT \& Victor TANNER, THE BROOKINGS INSTITUTION, SAIS PROJECT ON INTERNAL DiSPLACEMENT, THE INTERNALLY DiSPLACED PEOPLE OF IRAQ 29 (2002).

14. Marsh Arabs, supra note 4. 
reeds are gone, and along with them the smooth-coated otter, the crested porcupine, the grey wolf, the Basrah reed warbler, important staging areas for migrating waterfowl, countless fish and invertebrates, and a crucial food supply for the fish of the Persian Gulf. ${ }^{15}$ While the exact number of deaths and of persons displaced as a result will probably never be known, most sources estimate the number of displaced persons to be between 200,000 and $400,000 .^{16}$ A similar number may remain in the former marshes in a state of extreme poverty. ${ }^{17}$

\section{THE LEGALITY OF IRAQ'S ACTIONS UNDER INTERNATIONAL LAW}

At the time of its campaign against the Marsh Arabs, the government of Iraq was party to a number of international conventions bearing on its conduct. In addition, the government was subject to obligations under customary international law. This section will examine which obligations under those treaties or under customary international law were violated by Iraq's conduct.

\section{A. Sources of International Law}

Article $38(1)$ of the Statute of the International Court of Justice provides a traditional starting point for examining the sources of international law:

international conventions, ... international custom, as evidence of a general practice accepted as law, ... the general principles of law recognized by civilized nations, ... judicial decisions, and the teachings of the most highly qualified publicists of the various nations. $^{18}$

15. See AMAR International Charitable Foundation, The Marsh Arabs and the Marshlands, at http://www.amarappeal.com/about5.htm (last visited Oct. 9, 2003).

16. See, e.g., Marsh Arabs, supra note 4; Freeman, supra note 8. See generally THE IRAQI MARShLANDS: A HuMAN AND ENVIRONMENTAL STUdY (Emma Nicholson \& Peter Clark eds., 2002) (giving a detailed description of the environmental campaign against the Marsh Arabs) [hereinafter THE IRAQI MARSHLANDS]; see also FAWCETT \& TANNER, supra note 13 , at $29-32,40,51,54$.

17. The Baroness Emma Nicholson of Winterbourne, The Iraq Marshlands: Can They be Saved?, Address at Brookings Forum Sponsored by the British Embassy and the Brookings-SAIS Project on Internal Displacement (May 7, 2003), at http://www.brook.edu/comm/events/ 20030507marsh.htm (last visited Oct. 9, 2003).

18. Statute of the International Court of Justice, June 26, 1945, art. 38(1), 59 Stat. 1055, 
These sources can, with the exception of international conventions, be grouped together under the heading of "customary international law."19

\section{Conventional International Law: Treaties and Other International Agreements}

The environment has always suffered in warfare, but until the latter part of the twentieth century conventional international law had not addressed the problem directly. Environmental protection, where it existed at all, was contained in treaties dealing with other topics. The past century has brought about a dramatic increase in the destructive power available to warring states and factions, and a growing worldwide awareness of the fragility of the natural environment. Weapons now exist, and are available to many countries, that could render the planet unsuitable for human life. ${ }^{20}$

This increase in the environmental threat posed by warfare has brought about a corresponding increase in the attention given to the problem in international agreements. The watershed event in the development of law regarding the protection of the environment during wartime was the American defoliation campaign during the Vietnam War, which brought an unprecedented degree of international attention to the problem of environmental destruction during wartime. ${ }^{21}$ Prior to that time environmental protection had been incidental to other international agreements regulating the conduct of war, rather than a specific end in itself. Pre-Vietnam era treaties did not deal specifically with the problem of environmental protection during wartime, but provided some protection directly. Treaties of this nature to which Iraq is a party include the Convention Against Genocide, ${ }^{22}$ the 1925 Geneva Gas Protocol, ${ }^{23}$ and the

1060, 3 Bevans 1153, 1187.

19. See infra notes $31-33$ and accompanying text.

20. The supposed existence of such weapons in Iraq was offered by the governments of the United Kingdom and the United States as a justification for war with Iraq, ultimately resulting in considerable embarrassment for both governments.

21. See, e.g., Neil A.F. Popovic, Humanitarian Law, Protection of the Environment, and Human Rights, 8 GEO. INT'L ENVTL. L. REV. 67, $69-70$ (1995); Michael N. Schmitt, Green War: An Assessment of the Environmental Law of International Armed Conflict, 22 Yale J. INT'L L. 1, 9-10 (1997); Aaron Schwabach, Environmental Damage Resulting from the NATO Military Action Against Yugoslavia, 25 ColuM. J. ENVTL. L. 117, 126 (2000); Ensign Florencio J. Yuzon, Deliberate Environmental Modification Through the Use of Chemical and Biological Weapons: "Greening" the International Laws of Armed Conflict to Establish an Environmentally Protective Regime, 11 AM. U. J. INT'L L. \& POL'Y 793, 795-96 (1996).

22. Convention on the Prevention and Punishment of the Crime of Genocide, Dec. 9, 1948, 102 Stat. 3045, 78 U.N.T.S. 277 [hereinafter Genocide Convention].

23. Protocol for the Prohibition of the Use in War of Asphyxiating, Poisonous, or Other 
four Geneva Conventions of $1949 .^{24}$ Two agreements from the Vietnam War era that deal tangentially with environmental issues in a human rights context are the covenants on Economic and Cultural Rights ${ }^{25}$ and on Civil and Political Rights. ${ }^{26}$

Between the Vietnam War and the first Gulf War, that portion of the jus in bello ${ }^{27}$ dealing with environmental protection evolved significantly. A few post-Vietnam era treaties deal specifically with environmental damage during wartime and may have some relevance to the question of the legality of Iraq's conduct. Iraq is not a party to these agreements, but some of their provisions may have entered into customary international law. These include the Convention on the Prohibition of Military or Any Other Hostile Use of Environmental Modification Techniques (ENMOD), ${ }^{28}$ Protocols I and II to the Geneva Conventions of $1949,{ }^{29}$ and the Rome Statute of the International Criminal Court. ${ }^{30}$

\section{Note on Customary International Law}

Before discussing the treaties, it is necessary to take a preliminary look at customary international law. General rules of customary international

Gases and of Bacteriological Methods of Warfare, June 17, 1925, 26 U.S.T. 571, T.I.A.S. No. 8061 .

24. Convention for the Amelioration of the Condition of the Wounded and Sick in Armed Forces in the Field, Aug. 12, 1949, 6 U.S.T. 3114, 75 U.N.T.S. 31 [hereinafter Geneva Convention I]; Convention for the Amelioration of the Condition of the Wounded, Sick and Shipwrecked Members of the Armed Forces at Sea, Aug. 12, 1949, 6 U.S.T. 3217, 75 U.N.T.S. 85 [hereinafter Geneva Convention II]; Convention Relative to the Treatment of Prisoners of War, Aug. 12, 1949, 6 U.S.T. 3316, 75 U.N.T.S. 135 [hereinafter Geneva Convention III]; Convention Relative to the Protection of Civilian Persons in Time of War, Aug. 12, 1949, 6 U.S.T. 3516, 75 U.N.T.S. 287 [hereinafter Geneva Convention IV].

25. International Covenant on Economic, Social and Cultural Rights, Dec. 16, 1966, 993 U.N.T.S. 3.

26. International Covenant on Civil and Political Rights, Dec. 16, 1966, 999 U.N.T.S. 171, 6 I.L.M. 386.

27. The jus in bello is the body of international law pertaining to the conduct of war.

28. Convention on the Prohibition of Military or Any Other Hostile Use of Environmental Modification Techniques, Dec. 10, 1976, 31 U.S.T. 333, 1108 U.N.T.S. 151 [hereinafter ENMOD].

29. Protocol Additional to the Geneva Conventions of 12 August 1949, and Relating to the Protection of Victims of International Armed Conflicts, June 8, 1977, 1125 U.N.T.S. 3 [hereinafter Protocol I]; Protocol Additional to the Geneva Conventions of 12 August 1949, and Relating to the Protection of Victims of Non-International Armed Conflicts, June 8, 1977, 1125 U.N.T.S. 609. [hereinafter Protocol II]. Neither the United States nor Iraq is a party to either protocol, but portions of both may have become customary international law. (1998).

30. Rome Statute on the International Criminal Court, U.N. Doc. A/CONF. 183/9 
environmental and humanitarian law may bear on the lawfulness, or lack thereof, of Iraq's actions. In addition, provisions of some treaties to which Iraq is not a party may have entered into customary international law, and thus Iraq may have been bound by those provisions even if it was'not a party to the treaty.

Customary international law is generally described as the practice of states undertaken out of a sense of legal obligation, or opinio juris. Of the sources of law mentioned in Article 38(1) of the Statute of the International Court of Justice, ${ }^{31}$ all but the first could conceivably fall within the category of customary international law, although "general principles of law" have traditionally been seen as a third category of public international law. However, they can also be seen as "supplemental rules" or a "secondary source of law." J2 Judicial decisions and the teachings of the most qualified publicists are merely a "subsidiary means for the determination of rules of law." 33 In any event, judicial decisions and, to the extent that a state actually observes them, general principles of law are state practice undertaken from a sense of legal obligation, and thus form the basis for normative expectations.

\section{B. The Obligations of Iraq Under Conventional International Law}

\section{The Genocide Convention}

The attack on the southern Mesopotamian wetlands was probably the largest attack on the environment itself since Operation Ranch Hand, the American defoliation campaign in Vietnam, thirty years earlier. As in Vietnam, the environmental damage was not incidental; the purpose in both cases was to affect a significant change in the natural environment. But while the American campaign was intended to facilitate military maneuvers, the draining of the Iraqi wetlands was a deliberate effort to eradicate the Marsh Arabs and their culture by altering the environment upon which they and their culture depended.

Article IV of the Genocide Convention forbids any party from

31. These are "international custom, as evidence of a general practice accepted as law, ... the general principles of law recognized by civilized nations, ... judicial decisions, and the teachings of the most highly qualified publicists of the various nations." See Statute of the International Court of Justice, supra note 17.

32. See, e.g., RESTATEMENT (ThIRD) OF THE Foreign RELATIONS LAW OF THE UNITED STATES $\S 102(4) \mathrm{cmt} .1$ \& Reporter's Note 7 (1987).

33. Statute of the International Court of Justice, supra note 17. 
"deliberately inflicting on [a] group conditions of life calculated to bring about its physical destruction in whole or in part." the Marsh Arabs' homeland was within the scope of the Convention, at the time when Iraq had agreed to be bound by its terms. ${ }^{35}$ It is still possible that some of the persons responsible for designing and implementing the policy may be brought to trial under Article VI of the Convention. However, no steps have yet been taken either to try those responsible in the Iraqi court system or to set up a special tribunal for crimes committed by Iraqi officials in violation of international law. The official Iraqi response to allegations of genocide against the Marsh Arabs was cynical: the Parliamentary Speaker noted, "America wiped the Red Indians off the face of the earth and nobody raised an eyebrow." 36

\section{The Hague and Geneva Regimes}

For decades prior to the Vietnam War, principles of international law had been in place that should have prevented Operation Ranch Hand. The 1868 Declaration of St. Petersburg stated, "the only legitimate object which states should endeavor to accomplish during war is to weaken the military forces of the enemy." 37 The objective of Operation Ranch Hand was, in fact, to weaken the forces of the enemy by denying them forest cover. However, an additional restriction is imposed by the 1899 and

34. Genocide Convention, supra note 22 , at 280 . Iraq acceded to the Convention on Jan. 20, 1959; the United States became a party by ratification on November 25, 1988 , forty years after signing the Convention. See Genocide Convention, Status of Ratifications, Reservations and Declarations, available at http://www.unhchr.ch/html/menu3/b/treatylgen.htm (last visited August 20, 2003) [hereinafter Status of Ratifications].

35. The United States' ratification includes two reservations and five understandings. Understanding 4 addresses situations of this sort: "[A]cts in the course of armed conflicts committed without the specific intent required by article II are not sufficient to constitute genocide as defined by this Convention." Status of Ratifications, supra note 33. Iraq's accession to the Convention contains no such provision.

36. FAWCETT \& TANNER, supra note 13, at 32 (quoting a 1992 statement of then Parliamentary Speaker Saadi Mehdi Saleh). It's hard to know just where to begin taking issue with this remark, but the comparison is apt, if hardly admirable. During the wars between the United States government and the Plains Indians in the nineteenth century, government agents engaged in the systematic extermination of buffalo, or American bison, in a largely successful effort to eradicate the Plains Indians.

37. Declaration Renouncing the Use, in Time of War, of Explosive Projectiles Under 400 Grammes Weight. Saint Petersburg, Nov. 29/Dec. 11 1868, 138 Consol. T.S. 297, reprinted in THE LAwS OF ARMED CONFLiCTS: A COLleCtion of CONVENTIONS, RESOlUtIONS, AND OTHER DOCUMENTS 102-03 (Dietrich Schindler \& Jiri Toman eds., 1988). The odd date (Nov. 29/Dec. 11) is the result of a difference in the Russian and Gregorian calendars that persisted until the time of the Revolution. 
1907 Hague Conventions, which provided that "the right of belligerents to adopt means of injuring the enemy is not unlimited." 38 Article 23 of the 1907 Hague Convention prohibited the use of "poison or poisoned weapons," 39 although this protection was probably not intended to apply to poisons used against plants rather than people.

The Operation Ranch Hand/ENMOD pattern of a violation of the weak general prohibition in Article 23 followed by a post-war response creating a strong, specific prohibition mirrored that taken to the use of poison gas. The general provision in Article 23 was ignored by several of the warring parties in World War I; post-war reaction led to the more effective 1925 Geneva Gas Protocol. ${ }^{40}$ In the seventy-eight years since the adoption of the Protocol, poison gas has rarely been used, ${ }^{41}$ and its use has almost always been condemned as a violation of international law. ${ }^{42}$

The four Geneva Conventions of $1949,{ }^{43}$ embodying the new awareness of human rights that followed World War II, also contained early glimmerings of modern concepts of environmental protection during wartime. The Conventions prohibit the extensive destruction of property, when carried out unlawfully and wantonly and not justified by military necessity. ${ }^{44}$ They also prohibit willfully causing great suffering or injury to health. ${ }^{45}$ Environmental damage within a populated territory

38. Convention Respecting the Laws and Customs of War on Land, Oct. 18, 1907, 36 Stat. 2277, 205 Consol. T.S. 277 [hereinafter "1907 Hague Convention"]. The Convention was the fourth of thirteen to emerge from the 1907 Hague Peace Conference and is thus known as "Hague IV."

39. Id. art. 23.

40. Geneva Protocol for the Prohibition of the Use in War of Asphyxiating, Poisonous, or Other Gases and of Bacteriological Methods of Warfare, supra note 22.

41. One of the rare violators has been Iraq, which is believed to have used poison gas in its war with Iran and against its rebellious Kurdish population, although the latter use was internal and thus possibly outside the scope of the 1925 Protocol. Some writers are of the opinion that Iraq's release and burning of oil violated the 1925 Protocol. See, e.g., Okorodudu-Fubara, supra note 6, at 190-91.

42. See, e.g., G.A. Res. 134, U.N. GAOR, 46th Sess., Agenda Item 98, U.N. Doc. A/RES/46/134 (1992). (Condemning Iraq for its use of chemical weapons against Iraq's Kurdish population.)

43. Geneva Convention I, supra note 23, art. 50; Geneva Convention II, supra note 23, art. 51; Geneva Convention III, supra note 23, art. 130; Geneva Convention IV, supra note 23 , art. 147.

44. Geneva Convention I, supra note 23, art. 50; Geneva Convention II, supra note 23, art. 51; Geneva Convention IV, supra note 23, art. 147.

45. Geneva Convention I, supra note 23, art. 50; Geneva Convention II, supra note 23, art. 51; Geneva Convention III, supra note 23, art. 130; Geneva Convention IV, supra note 23, art. 147 . 
typically involves damage to property as well as a risk of suffering or injury to the inhabitants; thus environmental damage such as that caused by the American campaign in Vietnam or the Iraqi campaign against the Marsh Arabs would be included if the harm was inflicted willfully.

\section{Common Article 3}

At the 1949 Diplomatic Conference at which the four Geneva Conventions ${ }^{46}$ were adopted, there was considerable debate between those parties that wished the protections in the Conventions to apply to all armed conflicts, and those that wished it to apply only to conflicts between states. ${ }^{47}$ The result was Common Article 3, included in all four conventions. The portion of Common Article 3 that may have some bearing on the situation of the Marsh Arabs provides that:

In the case of armed conflict not of an international character occurring in the territory of one of the High Contracting Parties, each Party to the conflict shall be bound to apply, as a minimum, the following provisions:

(1) Persons taking no active part in the hostilities, including members of armed forces who have laid down their arms and those placed hors de combat by sickness, wounds, detention, or any other cause, shall in all circumstances be treated humanely, without any adverse distinction founded on race, colour, religion or faith, sex, birth or wealth, or any other similar criteria. ${ }^{48}$

An unknown number of Marsh Arabs were killed outright by Iraqi forces during the drainage operations, and far more were deprived of their homes and livelihoods. ${ }^{49}$ At this time, the "hostilities" were largely over, and most or all of those killed or otherwise treated inhumanely would have been taking no active part. And depriving people of their homes and livelihoods can hardly be considered humane treatment. But the protections in Common Article 3 are considerably less extensive than those contained in the remainder of the four Conventions and applicable to international armed conflicts, and more or less co-extensive with the

46. Geneva Conventions I, II, III, and IV, supra note 23.

47. See Charles Lysaght, The Scope of Protocol II and Its Relation to Common Article 3 of the Geneva Conventions of 1949 and Other Human Rights Instruments, 33 AMERICAN U. L. REV. 9, 12 (1983).

48. Geneva Convention I, supra note 23, art. 3; Geneva Convention II, supra note 23, art. 3; Geneva Convention III, supra note 23, art. 3; Geneva Convention IV, supra note 23, art. 3 .

49. See FAWCETT \& TANNER, supra note 13 , at 31 . 
protections contained in the Covenant on Civil and Political Rights. ${ }^{50}$ While they may address some deprivations of individual rights during the drainage campaign, they do not address the larger issue of the underlying illegality of the campaign itself.

\section{The Human Rights Covenants}

The relevant portions of the International Covenant on Economic and Cultural Rights ${ }^{51}$ and the International Covenant on Civil and Political Rights ${ }^{52}$ are identical. Article 1(2) of each convention provides that:

All peoples may, for their own ends, freely dispose of their natural wealth and resources without prejudice to any obligations arising out of international economic co-operation, based upon the principle of mutual benefit, and international law. In no case may a people be deprived of its own means of subsistence. ${ }^{53}$

Article 25 of the Covenant on Economic and Cultural Rights and Article 47 of the Covenant on Civil and Political Rights are also identical: "Nothing in the present Covenant shall be interpreted as impairing the inherent right of all peoples to enjoy and utilize fully and freely their natural wealth and resources." 54

These provisions illustrate the insoluble problems inherent in the idea of collective rights: What is a "people"? Are the Iraqis a "people"? If so, may they not exploit the waters of the Tigris, the Euphrates and the Shatt al-Arab as they see fit, even to the detriment of some subset of the Iraqi people? Are the Marsh Arabs a "people"? What if some Marsh Arabs actually believe the wetlands should be drained, or benefit from it? Who speaks for the Iraqi "people" or the Marsh Arab "people"? If the Marsh Arabs are not part of the Iraqi "people," then by extension the Kurds, Assyrians, Chaldeans, Turkomans, minority Sunni Arabs, and fragmented and disempowered Shiite Arabs, among others, are not part of the Iraqi "people," either; any multicultural state such as Iraq must

50. See International Covenant on Civil and Political Rights, supra note 26 , at arts. $4(2), 6,7 \& 10$.

51. International Covenant on Economic and Cultural Rights, supra note 25.

52. International Covenant on Civil and Political Rights, supra note 26. The Covenant also contains guarantees of rights identical or analogous to those in Common Article 3 of the Geneva Conventions. See id.

53. International Covenant on Economic and Cultural Rights, supra note 25, art. I(2); International Covenant on Civil and Political Rights, supra note 26, art. I(2).

54. Id. art. 25; International Covenant on Civil and Political Rights, supra note 26, art. 47. 
lack a cultural identity as a "people."

Collective or third-generation rights are most often discussed in relation to the rights of indigenous or minority "peoples," such as the Marsh Arabs. But the right to sovereignty over natural resources is generally discussed in relation to the rights of states and national populations, such as Iraq and the Iraqis. Customary international law probably recognizes no collective rights other than the right to existence (addressed by the Genocide Convention ${ }^{55}$ ) and the right to selfdetermination, ${ }^{56}$ both of which were violated by the Hussein government's actions. Debating these issues may provide hours of entertainment for academics, ${ }^{57}$ but as a practical matter, it means that the environmental provisions of these two covenants are too ambiguous to provide useful guidance. If the Marsh Arabs are a "people" within the meaning of the natural resource provisions of the Conventions, however, they have certainly been deprived of their means of subsistence in violation of the Conventions.

\section{Environmental Treaties}

Iraq is a party to fifty treaties with environmental provisions. ${ }^{58}$ of

55. See supra note 34 and accompanying text.

56. See, e.g., Feisal Hussain Naqvi, People's Rights or Victim's Rights: Reexamining the Conceptualization of Indigenous Rights in International Law, 71 IND. L. J. 673, 724 (1996).

57. For some thoughtful discussions of these issues, see, for example, PETER R. BAEHR, HUMAN RIGHTS: UNIVERSALITY IN PRACTICE (1999); Maila Stivens, Introduction: Gender Politics and the Reimagining of Human Rights in the Asia-Pacific, in HUMAN RightS AND GENDER Politics: ASIA- PACIFIC PERSPECtIVES 17 (Anne-Marie Hilsdon et al. eds., 2000); Penelope E. Andrews, Globalization, Human Rights and Critical Race Feminism: Voices from the Margins, 3 J. GENDER, RACE \& JUST. 373 (2000); Mahmood Monshipouri, Promoting Universal Human Rights: Dilemmas of Integrating Developing Countries, 4 YALE HUM. RTS. \& DEV. L.J. 25 (2001); Yash Ghai, Universalism and Relativism: Human Rights as a Framework for Negotiating Interethnic Claims, 21 CARDozo L. ReV. 1095 (2000); Li-ann Thio, Implementing Human Rights in ASEAN Countries: 'Promises to Keep and Miles to go Before I Sleep, ' 2 YALE HUM. RTS. \& DeV. L.J 1 (1999); Prudence E. Taylor, From Environmental to Ecological Human Rights: A New Dynamic in International Law?, 10 GEORGETOWN INT'L ENVTL. L. REV. 309 (1998); Eric J. Mitnick, Taking Rights Spherically: Formal and Collective Aspects of Legal Rights, 34 WAKE FOREST L. REv. 409 (1999).

58. ENTRI: Environmental Treaties and Resource Indicators, Iraq Country Summary, http://sedac.ciesin.columbia.edu:9080/entri/countryProfile.jsp (last visited Oct. 9, 2003) (on file with CJIELP). Iraq has also signed but not ratified two environmental treaties, one of which is ENMOD. ENMOD, supra note 28. Iraq has also, along with 80 other former members out of a total of 95 , denounced one treaty. International Convention for the Safety of Life at Sea, June 17, 1960, at http://sedac.ciesin.columbia.edu:9080/entri/texts/acrc/solas60.txt.html (last visited Oct. 9, 
these, there are a few that merit at least cursory examination in a discussion of the Marsh Arabs and the southern Mesopotamian wetlands: ${ }^{59}$ the Convention Concerning the Protection of the World Cultural and Natural Heritage; ${ }^{60}$ the United Nations Convention on the Law of the Sea; ${ }^{61}$ the International Plant Protection Convention; ${ }^{62}$ the International Covenant on Economic and Cultural Rights; ${ }^{63}$ the International Covenant on Civil and Political Rights; ${ }^{64}$ the Kuwait Regional Convention for Co-operation on the Protection of the Marine Environment from Pollution; ${ }^{65}$ and the Protocol for the Protection of the Marine Environment against Pollution from Land-Based Sources. ${ }^{66}$

Two of these can be dismissed fairly quickly. First, the International Plant Protection Convention is aimed at preventing the spread of plant diseases and protecting cultivated plants, not at protecting wild vegetation and plant habitat. ${ }^{67}$ Second, although the destruction of the wetlands is certain to cause an increase in marine pollution in the northern Persian Gulf, the United Nations Convention on the Law of the Sea does not address shore-based coastal marine pollution. Pollution of this sort is addressed by the Convention for the Prevention of Marine Pollution from Land-Based Sources, ${ }^{68}$ to which Iraq is not a party, and by the Kuwait Convention ${ }^{69}$ and its Protocol on Pollution from Land-

2003) (on file with Colorado Journal of International Environmental Law and Policy).

59. Iraq is not a party to the Ramsar Wetlands Convention. Convention on Wetlands of International Importance Especially as Waterfowl Habitat, Feb. 2, 1971, 996 U.N.T.S. 245, reprinted in 11 I.L.M. 963 (1972).

60. Convention Concerning the Protection of the World Cultural and Natural Heritage, Nov. 16, 1972, 27 U.S.T. 37, 1037 U.N.T.S. 151. [hereinafter World Heritage Convention].

61. United Nations Convention on the Law of the Sea, Dec. 10, 1982, 1833 U.N.T.S. 397, 21 I.L.M. 1261.

62. International Plant Protection Convention, Dec. 6, 1951, Art. II(3), 23 U.S.T. 2767, 150 U.N.T.S. 67 (revised Nov. 28, 1979).

63. International Covenant on Economic and Cultural Rights, supra note 25.

64. International Covenant on Civil and Political Rights, supra note 26.

65. Kuwait Regional Convention for Co-operation on the Protection of the Marine Environment from Pollution, Apr. 24, 1978, 1140 U.N.T.S. 133, 17 I.L.M. 511 (1978) [hereinafter Kuwait Convention].

66. Protocol for the Protection of the Marine Environment against Pollution from LandBased Sources, Feb. 21, 1990, (entered into force 1993) (on file with author) thereinafter Protocol to Kuwait Convention].

67. International Plant Protection Convention, supra note 62, art. II(3).

68. Convention for the Prevention of Marine Pollution from Land-Based Sources, June 14, 1974, U.K.T.S. 64 (1978), Cmnd. 7251, 13 I.L.M. 352.

69. Kuwait Convention, supra note 65. 
Based Sources. $^{70}$

A third international instrument, the Convention Concerning the Protection of the World Cultural and Natural Heritage, ${ }^{71}$ allows the designation of certain sites of cultural significance, natural significance, or both as World Heritage Sites, and sets up a fund to provide assistance in preserving these sites. The lower Mesopotamian wetlands are not designated as a World Heritage Site. ${ }^{72}$ A designated site in Iraq, Ashur, is threatened by a proposed dam and has been added to UNESCO's list of World Heritage Sites in Danger. ${ }^{73}$ Iraq's overall program of hydraulic and hydrologic engineering, which threatens Ashur, has also destroyed the southern Mesopotamian wetlands. However, even an expanded view does not mean that Iraq has violated or is likely to violate any obligations under the Convention.

The Convention imposes specific responsibilities on states with regard to natural or cultural heritage located in the territory of other states: "Each State Party to this Convention undertakes not to take any deliberate measures which might damage directly or indirectly the cultural and natural heritage ... situated on the territory of other States Parties to this Convention."74 In contrast, with regard to cultural and natural heritage in their own territory, states are subject to a somewhat more vague exhortation to "ensur[e] the identification, protection, conservation, presentation and transmission to future generations of the cultural and natural heritage. . situated on its territory." 75

The Kuwait Regional Convention for Co-operation on the Protection of the Marine Environment from Pollution provides that "The Contracting States shall take all appropriate measures to prevent, abate and combat pollution caused by discharges from land reaching the Sea Area whether water-borne, air-borne or directly from the coast including outfalls and pipelines." "Wh "While this at first seems more likely to be relevant to the situation of the Marsh Arabs and the southern Mesopotamian marshes, in fact it imposes little actual responsibility on

70. Protocol to the Kuwait Convention, supra note 66.

71. World Heritage Convention, supra note 60.

72. UNESCO, WORLD HERITAGE LIST, at http://whc.unesco.org/heritage.htm (last visited August 23, 2003). Somewhat surprisingly, considering Iraq's wealth of archaeological sites, only two World Heritage Sites are listed for Iraq. Id.

73. UNESCO, ASHUR, at http://whc.unesco.org/sites/1130.htm (last visited August 23, 2003) (describing Ashur); UNESCO, World Heritage LiST IN DANGer, at http://whc.unesco.org/toc/mainf4.htm (last visited August 23, 2003) (listing the world heritage sites in danger).

74. World Heritage Convention, supra note 60, art. 6(3).

75. Id. art. 4.

76. Kuwait Convention, supra note 65, art. VI. 
Iraq. The Convention requires Iraq to take "all appropriate measures," not "all possible measures" or "all necessary measures.",77

The 1990 Protocol for the Protection of the Marine Environment against Pollution from Land-Based Sources ${ }^{78}$ adds a requirement of environmental impact assessment for activities likely to cause pollution below the saltwater line ${ }^{79}$ and requires cooperation between states in the event of pollution from a transboundary watercourse such as the lower Mesopotamian wetlands and the Shatt al-Arab. ${ }^{80}$ It also provides that "[c]ontracting States shall ensure that recourse is available in accordance with their legal systems for prompt and adequate compensation or other relief in respect of damage caused by pollution of the Marine Environment by natural or juridical persons under their jurisdiction." ${ }^{, 81}$

The damage to the wetlands may itself be a polluting activity, leading to a short-term increase in the amount of organic matter discharged into the Persian Gulf with consequent eutrophication. The loss of the filtering capacity of the wetlands will also lead to an increase in the quantity of pollutants from other sources ultimately reaching the gulf. But although the Kuwait Convention and its Protocol may provide some recourse for Iraq's neighbors injured by increased marine pollution, they provide none for the Marsh Arabs. The suffering of the Marsh Arabs is the result of the destruction of the marshes, not the result of any consequent pollution of the marine environment.

\section{The Obligations of Iraq Under Customary International Law}

There are also some general principles of customary international law that may be applicable to the destruction of the southern Mesopotamian wetlands. Most customary law deals entirely with relations between states, however. While it might provide a remedy to Iran for damage to its portion of the wetlands, it offers none to the Iraqi Marsh Arabs. Customary law might, however, provide guidance in defining terms such as "military necessity" that could aid in application of conventional law.

The Martens Clause of the 1907 Hague Convention incorporates customary international law to fill any lacunae in the treaty regime

77. For a discussion of the significance of these and related differences in wording, see, for example, Aaron Schwabach, The United Nations Convention on the Law of NonNavigational Uses of International Watercourses, Customary International Law, and the Interests of Developing Upper Riparians, 33 TEX. INT’L L.J. 257, 272-73 (1998).

78. Protocol to the Kuwait Convention, supra note 66.

79. Id. art. VIII(1).

80. Id. art. $\mathrm{XI}(1)$.

81. Id. art. XIII(1). 
governing state conduct during wartime:

Until a more complete code of the laws of war has been issued. . the inhabitants and belligerents remain under the protection and the rule of the principles of the law of nations, as they result from the usages established among civilized peoples, from the laws of humanity, and the dictates of the public conscience. ${ }^{82}$

Thus treaties may derogate from customary international law, but in the absence of such provisions the rules of customary international law are binding on the parties to the Hague Convention. Note also that the Convention itself has attained, through widespread observance or at least aspiration, the status of customary international law. A certain amount of bootstrapping thus results in a universal body of customary international law on the topic, equally binding on all nations.

\section{Customary International Environmental Law}

Customary international law deals with transboundary rather than domestic environmental harm. ${ }^{83}$ The fundamental principle in this area of law is that each state has a duty not to allow its territory to be used so as to injure that of another. ${ }^{84}$ Principle 21 of the United Nations' Stockholm Declaration on the Human Environment, an aspirational document now widely accepted as a statement of customary international law, provides that states have the "sovereign right to exploit their own resources pursuant to their own environmental policies." 85 Along with this right, however, comes the "responsibility to ensure that activities within their jurisdiction or control do not cause damage to the environment of other States or areas beyond the limits of national jurisdiction."

82. 1907 Hague Convention, supra note 38 , at pmbl.

83. For a fuller exposition of the problems in some of these areas, see for example, Aaron Schwabach, Diverting the Danube: The Gabcikovo-Nagymaros Dispute and International Freshwater Law, 14 BERKELEY J. INT'L L. 290, 323-40 (1996).

84. See, e.g., Trail Smelter Case (U.S. v. Can.), 3 R.I.A.A. 1905, 1965 (1941), reprinted in 35 AM. J. INT'L L. 684 (1941); C. Channel Case (U.K. v. Alb.), 1949 I.C.J. 4, 22 (1949) (determination on the merits); Affaire du Lac Lanoux (Spain v. Fr.),

12 R.I.A.A. (1957), digested in 53 AM. J. INT'L L. 156 (1959).

85. Report of the United Nations Conference on the Human Environment, at Prin. 21, U.N. Doc. A/CONF.48/14/ Rev.1 (1972); see also World Charter for Nature, Oct. 28, 1982, G.A. Res. $37 / 7$ (Annex), U.N. GAOR, 37th Sess., Supp. No. 51, at 17, U.N. Doc. A/37/7, 22 I.L.M. 455 (1983); Rio Declaration on Environment and Development, June 14, 1992, U.N.Doc. A/CONF.151/26 (vol. 1), 31 I.L.M. 874 (1992).

86. Report of the United Nations Conference on the Human Environment, supra note 84; see also World Charter for Nature, supra note 84; Rio Declaration on Environment and Development, supra note 84. 
however, hold the view that Principle 21 is not applicable to wartime environmental damage. ${ }^{87}$

There is considerably less evidence of international custom when the destruction takes place within a single country. Principle 21 would seem to excuse such destruction as an exercise of the sovereign right to exploit resources. If, however, the Marsh Arabs are a different "people" from the other Iraqis, their situation may be analogous to that of an occupied territory. During World War II, for example, German civilian officials in occupied Poland were charged with "ruthless exploitation of Polish forestry" including "the wholesale cutting of Polish timber to an extent far in excess of what was necessary to preserve the timber resources of the country." 88 The Committee of the United Nations War Crimes Commission found that prima facie existence of a war crime had been shown and nine of the officials were listed as accused war criminals. ${ }^{89}$ Germany, however, had invaded Poland and was an occupying foreign power at the time. It may not be possible to stretch the definition of "occupied territory" to cover the homeland of the Marsh Arabs.

\section{Customary International Law Regarding "Military Necessity"}

Customary international law on transboundary environmental harm recognizes an exception for military necessity. Excessive environmental damage may be excused if it reasonably appeared necessary to the decisionmaker at the time the action was undertaken. ${ }^{90}$ The German officials who looted Poland's forest did not have any immediate military necessity for doing so; neither did the Iraqi government that drained the northern marshes.

The use of the military necessity exception is limited by the principles of proportionality, humanity, discrimination, and chivalry. ${ }^{91}$ Humanity requires that military forces avoid inflicting suffering, injury, or destruction beyond that actually necessary for the accomplishment of legitimate

87. See Low \& Hodgkinson, supra note 6 , at 445.

88. United Nations War Crimes Commission, Case No. 7150496 (1948).

89. U.N. WAR CRIMES COMMISSION, History OF THE UNITED Nations WAR CRIMES COMMISSION AND THE DEVELOPMENT OF THE LAWS OF WAR 496 (1948).

90. See, e.g., United States v. List, XI TrIals of WAR Criminals Before the NUREMBERg MiLTtary TRIBUNALS 1296 (1947-48). See also generally W. Hays Parks, Air War and the Law of War, 32 A.F. L. REv. 1, 3 (1990). Note that while this "reasonable commander" standard may provide protection for individual military officers in war crimes trials, it is not necessarily a defense to state liability.

91. See, e.g., INT'L \& Operational LAW Dep'T, The Judge AdVocate General's SCHOOL, U.S. ARMY, JA 442, OPERATIONAL LAW HANDBOOK, at 18-1, 18-2 (1996). 
military objectives, ${ }^{92}$ and discrimination requires that attackers distinguish military targets from civilian ones. ${ }^{93}$ The principle of chivalry relates to the use of subterfuge and is not likely to arise in an environmental context.

The principle of proportionality, on the other hand, is always at issue when questions of military necessity for inflicting environmental damage arise. Proportionality requires that the force used be proportional to the desired objective. ${ }^{94}$ For example, the 1938 destruction of the Huayuankow Dike by Nationalist forces during the Japanese invasion of China was disproportionate: the subsequent flooding killed several thousand Japanese soldiers and succeeded in halting the Japanese advance in the region, but it also killed hundreds of thousands of Chinese civilians-probably the greatest loss of life ever caused by a single human action-and caused untold economic damage. ${ }^{95}$ The destruction of the dike also violated the principles of humanity and discrimination.

The Iraqi actions also seem to have violated all three principles. The destruction of the wetlands was disproportionate to the goal of eliminating a handful of impoverished and already defeated rebels. Enormous suffering, injury and destruction were inflicted on the Marsh Arab population as a whole; the military goal of capturing the last few rebels could have been achieved with considerably less destruction. And although the vast majority of Marsh Arabs, and even the majority of villages, must have been uninvolved in the rebellion, there was no apparent attempt made to distinguish between civilian and rebel individuals or villages. Therefore, the military necessity exception seems not to apply.

\section{Conventions Pertaining to the Conduct of War with} Specifically Environmental Provisions to Which Iraq is Not a Party

\section{ENMOD}

The Convention on the Prohibition of Military or Any Other Hostile Use of Environmental Modification Techniques (ENMOD) ${ }^{96}$ was intended to prohibit the hostile use of large-scale environmental modification such as the deforestation practiced by the United States in Vietnam, as well as possible new forms of environmental modification including weather

92. See, e.g., Yuzon, supra note 21 , at 812.

93. See, e.g., id. at 810-11.

94. See, eg., id. at 810.

95. See, e.g., Caggiano, supra note 6 , at $\mathrm{n} .73$.

96. ENMOD, supra note 28. 
control and deliberate destruction of the ozone layer. ${ }^{97}$ ENMOD requires that the effect on the environment, in order to fall under the treaty, be "widespread, long-lasting, or severe." U8 Understanding I of the Conference of the Committee on Disarmament defines the terms as follows: "widespread" means extending over "several hundred square kilometers"; "long-lasting" means "approximately a season"; "severe" means causing "serious or significant disruption or harm to human life, natural and economic resources or other assets." 99 Note that ENMOD does not require that the disruption be widespread, long lasting, and severe; any one of the three is sufficient to constitute a violation.

The damage to the Mesopotamian wetlands meets all of these requirements. The marshes, which had covered an area of nearly 11,000 square kilometers in 1970 , had shrunk to 1,084 square kilometers by 2000 and 759 by $2002 .{ }^{100}$ The damage has lasted for many seasons and may be permanent, although plans for restoration have been proposed. ${ }^{101}$ And there has been serious disruption to human life and natural and economic resources: hundreds of thousands of people have been forced to leave their homes and live as impoverished refugees either within Iraq or across the border in Iran. There has also been widespread loss of animal and plant life, with disruption to fisheries and water supplies. ${ }^{102}$

However, Iraq is not a party to ENMOD; it signed the treaty in 1977 , but has not ratified it or deposited instruments of accession. ${ }^{103}$ It is thus not bound by the treaty unless ENMOD's provisions have attained the status of customary international law through widespread observation in the practice of states out of a sense of legal obligation. The expanded definitions in

97. See Schmitt, supra note 21 , at $82-85$. (providing a much more complete discussion of ENMOD)

98. ENMOD, supra note 28 , art. I(1).

99. Yuzon, supra note 21, at 806 (citing Understandings I \& II of the Conference of the Committee on Disarmament, reprinted in DOCUMENTS ON THE LAW OF WAR 377-78 (Adam Roberts \& Richard Guelff eds., 2d ed. 1989)).

100. UNEP, "Jardin de l'Eden" au sud de l'Irak risque de disparaître d'ici 5 ans, Mar.

22, 2003, available

at

http://www.grid.unep.ch/activities/sustainable/tigris/marshlands/index.fr.php (last visited August 22, 2003).

101. For example, an Iraqi expatriate group, the Iraq Foundation, seeks U.S. government funding for its plans to restore the marshes. See, e.g., Bayan Rahman and Frances Williams, Environmentalists Head to Rescue of Marshes, Financial Times, Apr. 12,2003 , at 5 .

102. See generally, e.g., AMAR International Charitable Foundation, supra note 15; Marsh Arabs, supra note 4; Freeman, supra note 8; THE IRAQI MARSHLANDS, supra note 16; FAWCETT \& TANNER, supra note 13.

103. See, e.g., ENMOD, PARTIES AND SIGNATORIES (2001) at http://www.sunshineproject.org/enmod/parties.html (last visited Oct. 26, 2003). 
Understanding I of the Conference of the Committee on Disarmament, at least, have not attained that status; many of the parties to ENMOD, in fact, have dissented from them. ${ }^{104}$ Thus, Understanding I does not represent a consensus even among the parties as to the meaning of these terms.

The language in the treaty itself prohibiting military use of "widespread, long-lasting, or severe" environmental modification may have become customary international law and may therefore be binding on Iraq, unless Iraq has consistently dissented. Warring states, even those not bound by ENMOD, have for the most part refrained from such acts. ${ }^{105}$ When they have not refrained (as Saddam Hussein's Iraq did not), the action has generally been met with universal disapproval. Thus, there seems to exist an international sense of legal obligation to refrain from strategic or tactical use of widespread, long-lasting, or severe environmental modification. However, ENMOD confines itself to prohibiting the use of such techniques by one state against another state: a purely internal conflict is outside the scope of the treaty and thus outside the scope of any customary legal principles arising therefrom. ${ }^{106}$

\section{Protocol I}

Protocol I was drafted by the International Committee of the Red Cross between 1974 and 1977; Iraq is not a party. ${ }^{107}$ The United States, which signed the Protocol in 1978 but has not yet ratified it, takes the position that much of Protocol I is customary law and thus binding. ${ }^{108}$ For the most part this seems to be borne out in the practice of states.

In the post-World War II world, conflicts within states have been far more common than conflicts between states, although the line is often very difficult to draw. The dispute over how to treat internal armed conflicts, which had led to the adoption of Common Article 3 in the four 1949 Geneva Conventions, arose again in the negotiations leading to the

104. Yuzon, supra note 21 , at 807.

105. The United States, incidentally, is a party to ENMOD. ENMOD, supra note 27.

106. Id. art. I(1).

107. See International Committee of the Red Cross, Protocol additional to the Geneva Conventions of 12 August 1949 and Relating to the Protection of VICTIMS OF INTERNATIONAL ARMED CONFLICTS (PROTOCOL I) 8 JUNE 1977, at http://www.icrc.org/ihl.nsf/919ea1456cfe9058c12563da00617b39/d9e6b6264d7723c3cl 2563cd002d6ce4?OpenDocument (last visited November 22, 2003); INTERNATIONAL COMMitTeE OF tHE Red Cross, States Parties aNd Signatories, at http://www.icrc.org/ihl.nsf/NORM?OpenView\&Start=1\&Count $=150 \&$ Expand $=52.1 \# 52.1$ (last visited November 22, 2003) [hereinafter STATES PARTIES].

108. See Schmitt, supra note 3 , at 69. 
adoption of Protocols I and II. Many countries proposed that there should be little or no difference in the treatment of internal and international armed conflicts. Norway, for example, successfully urged the adoption of a provision applying the provisions of the four 1949 Conventions and Protocol I to "armed conflicts in which peoples are fighting against colonial domination and alien occupation and against racist regimes in the exercise of their right of self-determination." 109

There is considerable ambiguity here: At what point does an armed conflict become a struggle against colonial domination or alien occupation? The Marsh Arabs were not subject to colonial domination or alien occupation in the traditional sense. They do not (or did not) possess national aspirations and national liberation movements as do, for example, the Kurds of northern Iraq. A regime that characterized the Marsh Arabs as "monkey-faced" and "not real Iraqis" 110 is certainly discriminatory, but whether it is racist depends on what is meant by "race" and "racist."

"Racist regimes" was, at the time of its inclusion, a specific reference to the governments of South Africa and what was then Rhodesia. The commentary on Protocol I refers to "minority racist regimes," "but also states that the term can refer to "if not the existence of two completely distinct peoples, at least a rift within a people which ensures hegemony of one section in accordance with racist ideas." While the Marsh Arabs are not a separate race from the majority of Iraqis or from the ruling religious minority during the Hussein years, there was evidently a rift between them and the ruling group, and that group's hegemony over the Marsh Arabs, if not over the country as a whole, appeared to be based on racist ideas.

Most of the environmental protection provided by Protocol I is, like all such protection previously, indirect. Protocol I also contains direct environmental protections, however. Article 35(1) reiterates the Hague Convention principle that "[i]n any armed conflict, the right of the Parties to the Conflict to choose methods or means of warfare is not unlimited[.]"113 Article 35(3) makes this provision specifically applicable

109. Protocol I, supra note 29, art. 1(4); Lysaght, supra note 47, at 9-10.

110. See FAWCETT \& TANNER, supra note 13, at 29.

111. InTERnational COMmITTEe OF THE Red CROSS, COMMENTARY ON PROTOCOL Additional to the Geneva Conventions of 12 August 1949, and Relating to tHe Protection of Victims of INTERnational Armed Conflicts (Protocol I), 8 June 1977, ף 80 , available at http://www.icrc.org/ihl.nsf/COMART?openview (last visited August 24, 2003) [hereinafter COMMENTARY ON PROTOCOL I].

112. Id. art. $1, \$ 112$.

113. Protocol I, supra note 29, art. 35(1). 
to the environment: "[i]t is prohibited to employ methods or means of warfare which are intended, or may be expected, to cause widespread, long-term, and severe damage to the natural environment."114

At first glance the wording might appear identical to that of ENMOD, but the choice of conjunction makes an enormous difference: ENMOD prohibits techniques having "widespread, long-lasting or severe" effects, ${ }^{115}$.while Protocol I aims to prevent "widespread, longterm, and severe" damage. ${ }^{16}$ The Protocol I standard is thus much higher than the ENMOD standard: all three elements must be met, rather than merely one. There is no reason to assume that the definitions of "widespread, long-term, and severe" contained in Understanding I, which as noted are not customary international law, are applicable to Protocol I. On the contrary, the commentary to Article 55, which uses the same phrase, states that "[i]n the final debate several delegations indicated that in their opinion the words 'widespread, long-term and severe' do not have the same meaning in the Protocol as the corresponding words in [ENMOD]."117 The United States delegation expressed the opinion that Article 35 governed a wider scope of activity than ENMOD, as it covered harm inflicted upon the environment by any means rather than only the use or modification of the environment itself as a weapon. ${ }^{118}$ By almost any conceivable measure, however, the damage done to the homeland of the Marsh Arabs seems likely not only to meet but to exceed the minimum threshold for all three elements.

Article 54 of Protocol I prohibits attacking, destroying, or rendering useless "objects indispensable to the survival of the civilian population," including drinking water supplies and installations and agricultural areas for the production of foodstuffs. ${ }^{119}$ While the draining of the wetlands undoubtedly affected water supplies and production of foodstuffs, the wetlands and watercourses may not be "objects" within the meaning of Article 51. The commentary to Article 54 suggests that they may be:

[T] indispensable to the survival of the civilian population," while Article 69 . . refers to ... "supplies essential to the survival of the civilian population" (while the title uses the term "basic needs"). In the French text of these two articles the difference in terminology is only in the adjective: reference is made to "biens indispensables" and

114. Id. at art. 35(3).

115. ENMOD, supra note 27, art. I(1).

116. Protocol I, supra note 29, art. 35(3)

117. COMMENTARY ON PROTOCOL 1, supra note 111, art. 55, $\uparrow 2136$.

118. Id. at $\uparrow 1450$; see generally id. art. $35,9 \uparrow 1447-58$.

119. Protocol I, supra note 29, art. 54(2). 
"biens essentiels", respectively. In their contexts the two terms must be considered to have the same meaning. ${ }^{120}$

This is incorrect, however. Article 54 does indeed refer, in the title and in the text, to "biens indispensables;" the English version uses "objects indispensable [to the survival of the civilian population]." 21 The title of Article 69 uses the term "besoins essentiels," however, while the text refers to "approvisionements essentiels." 22 In the English text of Article 69 , the corresponding terms are "basic needs" and "supplies essential [to the survival of the civilian population]."123

In addition, the destruction of the wetlands did have "the specific purpose of denying them for their sustenance value to the civilian population" and did "leave the civilian population with such inadequate food and water as to cause its starvation or force its movement," as prohibited by Article 54. ${ }^{124}$ The destruction was also carried out as a reprisal, also prohibited: "[ $t]$ hese objects shall not be made the object of reprisals." 125

Article 55 of the Protocol is aimed purely at protection of the environment and of civilian populations dependent upon it:

Care shall be taken in warfare to protect the natural environment against widespread, long-term, and severe damage. This protection includes a prohibition of the use of methods or means of warfare which are intended to or may be expected to cause such damage to the natural environment and thereby to prejudice the health or survival of the population. ${ }^{126}$

In addition, "[a]ttacks against the natural environment by way of reprisals are prohibited." ${ }^{\prime 27}$ This treaty provision was designed to prohibit exactly the type of harm that occurred in southern Iraq: retaliation against a civilian population by damaging the environment upon which that population depended for its health and survival.

Thus, Iraq would at first appear to be in violation of the terms of Protocol I. And if, as seems likely, the environmental provisions of

120. COMMENTARY ON PROTOCOL I, supra note 111 , art. 54 ף2086.

121. Protocol 1, supra note 29, art. 54(2).

122. Protocole additional aux Conventions de Genève du 12 août 1949 relatif à la protection des victims des conflits armés internationaux, June 8, 1977, 1125 U.N.T.S. 271, arts. 54, 69. (French text of Protocol I).

123. Id. art. 69.

124. Id. art $54(2)$.

125. Id. art. 54(4).

126. $I$ d. art. $55(1)$.

127. Id. art. 55(2). 
Protocol I have become part of customary international law, Iraq would seem to be in violation of those provisions even though it is not a party to the Protocol, unless it has been a consistent dissenter.

But if the Marsh Arabs were not struggling against a racist regime in exercise of their right of self-determination, Protocol I will be inapplicable because the draining of the wetlands and attacks on the Marsh Arabs happened largely within the borders of Iraq. While the portion of the wetlands lying in Iran has also, inevitably, been affected, those effects seem to have been incidental; the Iraqi wetlands were the primary target. ${ }^{128} \mathrm{~A}$ separate document, Protocol II, applies to armed conflicts within the borders of a single state.

\section{Protocol II}

Protocol II was adopted to cover non-international conflicts that were not struggles against colonial domination, alien occupation or racist regimes. ${ }^{129}$ The coverage of Common Article 3, Protocol II and Protocol I can be thought of as three concentric circles. The outer, largest circle is Common Article 3; it applies to all non-international armed conflicts. The middle circle is Protocol II; it applies to non-international armed conflicts in which the rebels "exercise such control over a part of [the state's] territory as to enable them to carry out sustained and concerted military operations and to implement" Protocol II. ${ }^{130}$ The inner circle is Protocol I; it applies only to international conflicts and to conflicts "in which peoples are fighting against colonial domination and alien occupation and against racist regimes in the exercise of their right of selfdetermination[.]"131 Conceivably the inner two circles are not concentric, but overlapping; there may be anti-colonial rebel groups that do not exercise control over territory sufficient to allow them to implement Protocol II, but would nonetheless be covered by Protocol I and the four 1949 Conventions.

Although the protections of Protocol II are less extensive than those of Protocol I, Protocol II does contain some measures protecting the

128. This does not mean that Iran has no recourse against Iraq for damage to its territory; traditional principles of state responsibility would still apply. See infra notes 118-20 and accompanying text.

129. See Protocol II, supra note 29, Art. I; See also INTERNational COMMITTEE OF

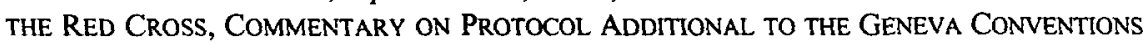
OF 12 August 1949, AND Relating to the PROTECTION OF Victims of NON-INTERNATIONAL ARMED CONFLICTS (PROTOCOL II), 8 JUNE 1977, 99 4446-79, available at http://www.icrc.org/ihl.nsf/COMART?openview (last visited August 24, 2003).

130. Protocol II, supra note 29, art. I(1).

131. Protocol I, supra note 29 , art. I(4). 
environment. Article 14 of Protocol II is similar to Article 54(1) and (2) of Protocol I, but somewhat more narrowly worded. Article 14 provides:

Starvation of civilians as a method of combat is prohibited. It is therefore prohibited to attack, destroy, remove or render useless, for that purpose, objects indispensable to the survival of the civilian population, such as foodstuffs, agricultural areas for the production of foodstuffs, crops, livestock, drinking water installations and supplies and irrigation works. ${ }^{132}$

In contrast, Article 54 of Protocol I provides:

1. Starvation of civilians as a method of warfare is prohibited. ${ }^{133}$

2. It is prohibited to attack, destroy, remove or render useless objects indispensable to the survival of the civilian population, such as foodstuffs, agricultural areas for the production of foodstuffs, crops, livestock, drinking water installations and supplies and irrigation works, for the specific purpose of denying them for their sustenance value to the civilian population or to the adverse Party, whatever the motive, whether in order to starve out civilians, to cause them to move away, or for any other motive. ${ }^{134}$

The minor textual difference has significant consequences for the Marsh Arabs. Protocol I, possibly inapplicable to their situation, places the prohibition of destroying indispensable objects in a separate numbered paragraph from the prohibition of starvation. That separate paragraph elaborates further: It is illegal not merely to destroy these objects to starve the civilian population, but also to destroy them to cause the civilians to move away or for any other reason.

If Protocol I were applicable to the situation, a violation could be proved by showing that the marshes were an indispensable object. While this might be difficult, under Protocol II there is a second hurdle: the motive of the Hussein government must have been to starve the civilian population, rather than to injure them in some other way. (Note, though, that the exceptions in Articles 54(1) and 54(3) of Protocol I do not apply to Article 14 of Protocol II.) Even more distressing is the absence in Protocol II of any specifically environmental provision analogous to Article 55 of Protocol I. There is, however, a prohibition on the forced movement of civilians in Article 17 of Protocol II:

1. The displacement of the civilian population shall not be ordered for reasons related to the conflict unless the security of the

132. Protocol II, supra note 29, art. 14.

133. Protocol I, supra note 29, art. 54(1).

134. Id. art. 54(2). 
civilians involved or imperative military reasons so demand. Should such displacements have to be carried out, all possible measures shall be taken in order that the civilian population may be received under satisfactory conditions of shelter, hygiene, health, safety and nutrition.

2. Civilians shall not be compelled to leave their own territory for reasons connected with the conflict. ${ }^{135}$

This provision seems to have been violated. The Marsh Arabs were forced to relocate by the destruction of their environment, and in some cases at gunpoint and by the burning of their villages. This was certainly not for their security. The conflict had already ended, so there could not have been any immediate military necessity, although the Hussein government might have imagined a long-term necessity. "All possible measures" were not taken to ensure that the Marsh Arabs were "received under satisfactory conditions of shelter, hygiene, health, safety and nutrition," as their situation today shows. However, Iraq is not a party to Protocol I or II. ${ }^{136}$ Even if the provisions of the Protocols have, as the U.S. maintains, entered into customary law, Iraq has in all probability been a consistent dissenter, preventing the formation of any normative expectation that Iraq will act in accordance with the Protocols or feels obligated to do so.

While countries such as Norway may feel that a single standard should apply to all armed conflicts, ${ }^{137}$ a cynic might observe that the probability that Norway will suffer an internal armed conflict at any time in the foreseeable future is remote. Countries that are more likely to experience such conflicts, including Iraq, may have a greater stake in the formation of rules regarding those conflicts. Nonetheless, it is possible that the provisions of the Geneva Conventions are jus cogens, a norm from which Iraq cannot derogate, ${ }^{138}$ although that may not be true of the 1977 Protocols. ${ }^{139}$

135. Protocol II, supra note 29, art. 17.

136. See supra note 107 (Iraq not a party to Protocol 1); STATES PARTIES, supra note 107.

137. See supra note 109 and accompanying text.

138. See, e.g., M. Cherif Bassiouni, Universal Jurisdiction for International Crimes: Historical Perspectives and Contemporary Practice, 42 VA. J. INT'L L. 81 (2001).

139. See, e.g., Hilaire McCoubrey, International Humantarian law 195 (1990). "It might, in the light of the very large number of states party to them, be argued that the whole of the 1949 Geneva Conventions, although not of the 1977 Additional Protocols, have been absorbed into the body of jus cogens." Id. This approach to jus cogens may be somewhat more skeptical than that of many scholars, although a similar or greater skepticism is expressed by many governments. The debate over the existence, 


\section{The Rome Statute}

The Rome Statute establishes a permanent International Criminal Court to adjudicate crimes against humanity. ${ }^{140}$ Article $8(2)(b)(i v)$ of the Rome Statute prohibits:

[i]ntentionally launching an attack in the knowledge that such attack will cause incidental loss of life or injury to civilians or damage to civilian objects or widespread, long-term, and severe damage to the natural environment which would be clearly excessive in relation to the concrete and direct overall military advantage anticipated. ${ }^{141}$

Iraq's attack on the southern Mesopotamian wetlands was launched not only with the knowledge but also with the intention that it would cause "widespread, long-term, and severe damage to the natural environment." (Note that the standard is identical to that in Articles 35(3) and 55 of Protocol I. $)^{142}$ It certainly seems excessive in relation to any military advantage obtained. Iraq, however, is not a party to the Rome Statute. ${ }^{143}$

\section{CONCLUSION}

The various environmental treaties to which Iraq is a party, and customary international law regarding transboundary environmental harm, provide little recourse for the Marsh Arabs, although they may provide the basis for claims to be pursued by neighboring states. Conversely, the former Iraqi government is not likely to be exonerated on grounds of military necessity.

Environmental destruction as a means to achieving military objectives during wartime seems likely to continue. Even the smallest degree of military advantage during combat may be worth an enormous amount of post-war disapproval. In addition, rebel soldiers are not likely to restrain their actions for military reasons; if they fail to achieve their military objectives and are defeated by the state against which they are fighting, they can expect to be imprisoned or executed in any event. A trial for

nature and extent of jus cogens norms is extensive, and beyond the scope of this paper.

140. Rome Statute, supra note 30; see also UN, ROME STATUTE OF THE INTERNATIONAL CRIMINAL COURT, at http://www.un.org/law/icc/ (last visited August 23, 2003).

141. Rome Statute, supra note 30, art. 8(2)(b)(iv).

142. See supra notes 113-119 and accompanying text.

143. See Rome Statute, supra note 30; see also UN Multilateral Treaties Deposited With the Secretary General, ROME STATUTE of the INTERNational CRIMINAL COURT (1988), at http://untreaty.un.org/ENGLISH/bible/englishinternetbible/partI/chapterXVIII/treaty 10.asp (last visited August 23, 2003). 
environmental war crimes is a remote concern. The lack of any effective constraint on the rebel side may lead to a lack of restraint on the government side. Balanced against these considerations is self-interest: the territory the government is harming in a non-international conflict is, ultimately, its own territory. In addition to international disapproval, the offending government will ultimately bear the costs of the damage.

For the Marsh Arabs themselves, the future is uncertain. Restoration projects, involving removing the dikes and re-flooding the former marshlands, are being discussed, but such projects will require a great deal of money that is not likely to be forthcoming while the political situation in Iraq remains unstable. Even if restoration is funded, it is unlikely that the marshes can be fully returned to their original condition. And even if significant restoration is possible, many of the Marsh Arabs may have drifted away or perished, although some will doubtless return. ${ }^{144}$ In the meantime, the best way to prevent others from suffering a similar fate is to hold those responsible accountable under international law.

144. See, e.g., Freeman, supra note 8; Spoils of War, supra note 1; Marsh Arabs, supra note 4. 